\title{
Sliding layer estimation of shallow landslides on Aso volcanic mountains in Japan based on tephra layer-physical properties of soil
}

\author{
Mega Lia Istiyanti', Satoshi Goto ${ }^{2^{*}} \mathbb{D}$, Takashi Kimura ${ }^{3}$, Go Sato ${ }^{4}$, Shintaro Hayashi ${ }^{5}$, Akihiko Wakai ${ }^{6}$ and \\ Daisuke Higaki ${ }^{7}$
}

\begin{abstract}
Shallow landslides occur frequently on the Aso volcanic mountains. The soil materials on the Aso volcanic mountains consist of tephra layers formed by volcanic activities. This study is aimed to specify the physical properties of soil that correlate with the sliding layer of a shallow landslide on the volcanic mountain area. Tephra layers consist of kuroboku and scoria layers and the differences between these layers were specified using the physical properties of soil methods. Results showed that the plasticity index and the fine fraction content can be used for estimating the sliding layer in the Aso volcanic area.
\end{abstract}

Keywords: Aso volcano mountains, Fine fraction content, Plasticity index, Shallow landslides, Sliding layer, Tephra layer

\section{Introduction}

Shallow landslides occur frequently on the Aso volcanic mountains. Sediment disasters caused by the landslides repeatedly occurred in June 1953, July 1990, and June 2001, with the last one occurring on July 12th, 2012 (Goto and Kimura 2019; Higaki et al. 2019; Kimura et al. 2019; Miyabuchi et al. 2004) when a cumulative rainfall of $508 \mathrm{~mm}$ triggered numerous landslides throughout the month. The soil materials in the shallow landslides on the Aso volcanic mountains consist of tephra layers formed by volcanic activities. The tephra distribution was studied by Miyabuchi et al. (2004) and Ono and Watanabe (1985).

The sliding layer of the shallow landslides on the Aso volcanic mountains has been observed based on the difference in the value of hydraulic conductivity (Shimizu and Ono 2016). The layer below the sliding layer has lower hydraulic conductivity and the difference in the hydraulic conductivity was the control on the tephra layer (Shimizu and Ono 2016). Furthermore, Sato et al.

\footnotetext{
* Correspondence: goto@yamanashi.ac.jp

${ }^{2}$ Faculty of Engineering, Graduate Faculty of Interdisciplinary Research, University of Yamanashi, Kofu, Japan

Full list of author information is available at the end of the article
}

(2017) and Sato et al. (2019) observed that the gravitational deformation of the slope deposits on the Aso volcanic mountains resulted from the "flow" of the highly permeable kuroboku layer over the less permeable tephra layer.

However, the observation on the physical properties of the tephra layer has not been clearly explained. The purpose of this study aimed to observe the physical properties of soil that can be used for estimating the sliding layer of the shallow landslide on the volcanic mountain area. The soil materials were characterized using the period of volcanic activities, and laboratory tests were performed to observe the physical properties of tephra layers. Characteristics of tephra layers will be observed from the physical properties of soil by considering the stratigraphic analysis of field observations.

\section{Material and methods Field measurements \\ Two locations of the shallow landslide in Takadake were selected as the research area (Fig. 1). Takadake 1 is lo- cated at $32^{\circ} 53^{\prime} 54.06^{\prime \prime} \mathrm{N}, 131^{\circ} 7^{\prime} 33.47^{\prime \prime}$ E with land- slide dimensions of $34 \mathrm{~m}$ in length and $10 \mathrm{~m}$ in width.}




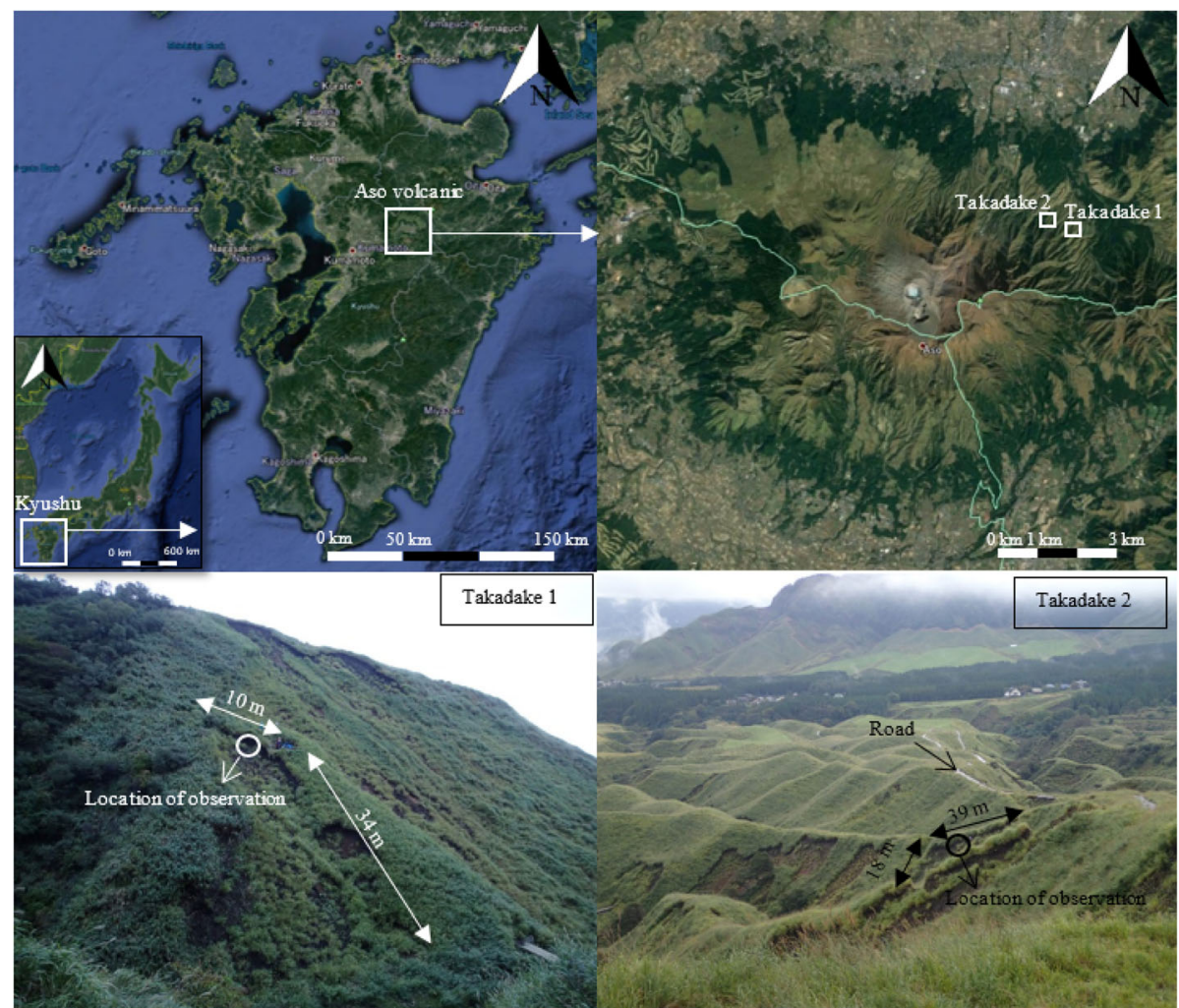

Fig. 1 Shallow landslides in Aso mountains (Photos taken on October 2016) (Scale measured by geolocation software)

The main soil layer was divided into 6 sub-layers from the surface down to a depth of $1.39 \mathrm{~m}$ (Fig. 2). Takadake 2 is located at $32^{\circ} 54^{\prime} 8.22^{\prime \prime} \mathrm{N}, 131^{\circ} 7^{\prime} 13.74^{\prime \prime}$ E with landslide dimensions of $18 \mathrm{~m}$ in length and $39 \mathrm{~m}$ in width. The main soil layer in Takadake 2 was divided into 7 sub-layers from the surface down to a depth of $1.37 \mathrm{~m}$ (Fig. 2). The main soil layers in each area were defined from the surface down to $1.40 \mathrm{~m}$ because exposure of the lowest sub-layer, Ojodake (OJS) scoria, was difficult.

The soil hardness value was measured using the Yamanaka-type soil hardness meter, which measures the soil hardness by pushing the device into the exposed soil layer at the site. In this study, the soil hardness values of each sub-layer at Takadake 1 and of several sub-layers at Takadake 2 were measured.

\section{Laboratory tests}

The physical property tests of soil performed in this study include particle size distribution, liquid limit and plastic limit, density of soil particles, and ignition loss, which were performed according to the laboratory testing standards of Geomaterials Vol. 1. Japanese Geotechnical Society Standards (2015). Laboratory tests were performed to observe the physical properties of tephra layers in this study.
Particle size distribution test was performed to observe the relation between particle size $(\mathrm{mm})$ and mass percentage passing (\%) (JIS A1204, 2009 cited in JGS, 2015). Furthermore, the water content of the soil under different conditions, transition from plastic to liquid state (liquid limit), and transition from plastic to semi-solid state (plastic limit) can be obtained by the liquid limit and plastic limit tests (JIS A1205, 2009 cited in JGS, 2015). The density of soil particles test was also performed to observe the mass per unit volume of the solid part of the soil (JIS A1202, 2009 cited in JGS, 2015). Moreover, the percentage of the reduction in soil mass when heated to $(750 \pm 50)^{\circ} \mathrm{C}$ relative to the soil mass when oven-dried to a constant mass at $(110 \pm 5){ }^{\circ} \mathrm{C}$ can be obtained by the ignition loss test (JIS A1226, 2009 cited in JGS, 2015). The organic matter test was performed according to Condie (1993), where the organic matter was specified by using oven-dried samples in ceramic crucibles with a capacity of $50 \mathrm{~mL}$ at a temperature of $550^{\circ} \mathrm{C}$ for $4 \mathrm{~h}$.

\section{Results and discussion}

\section{Stratigraphic analysis of the field observations}

Figure 2 shows the tephra layer field observations. At each area, the kuroboku colour is nearly black, which is darker than the scoria layers. Kuroboku layers are located on the scoria layers in each area. Takadake 1 has 
(a) Takadake 1

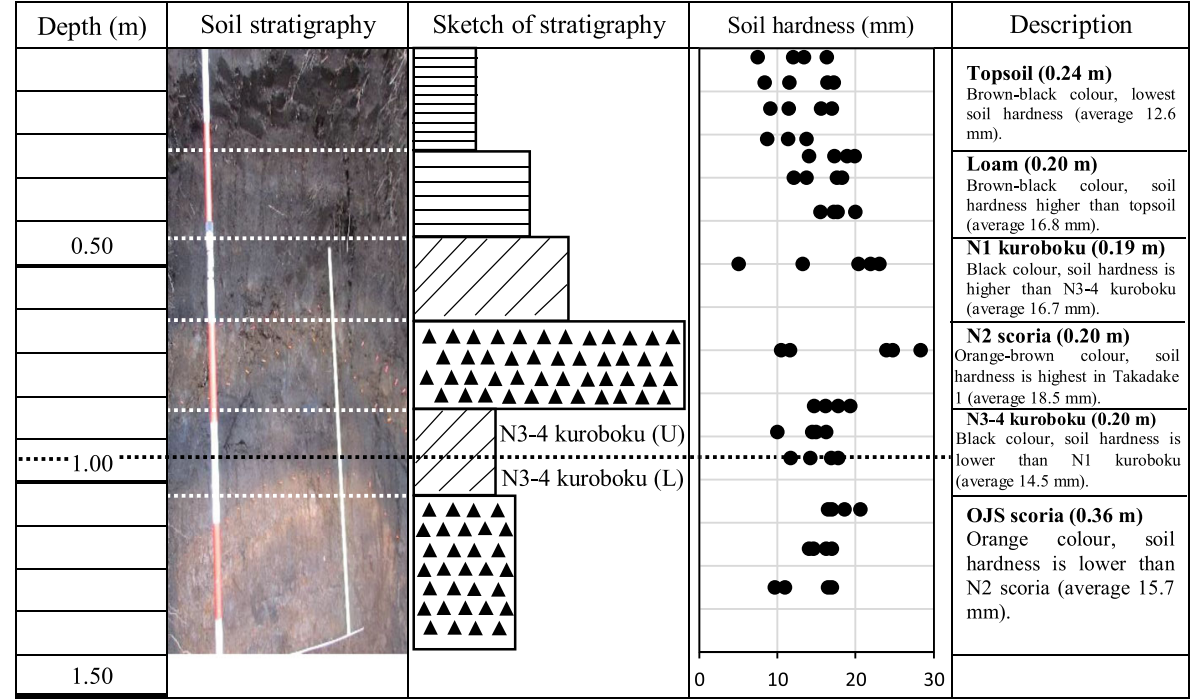

(b) Takadake 2

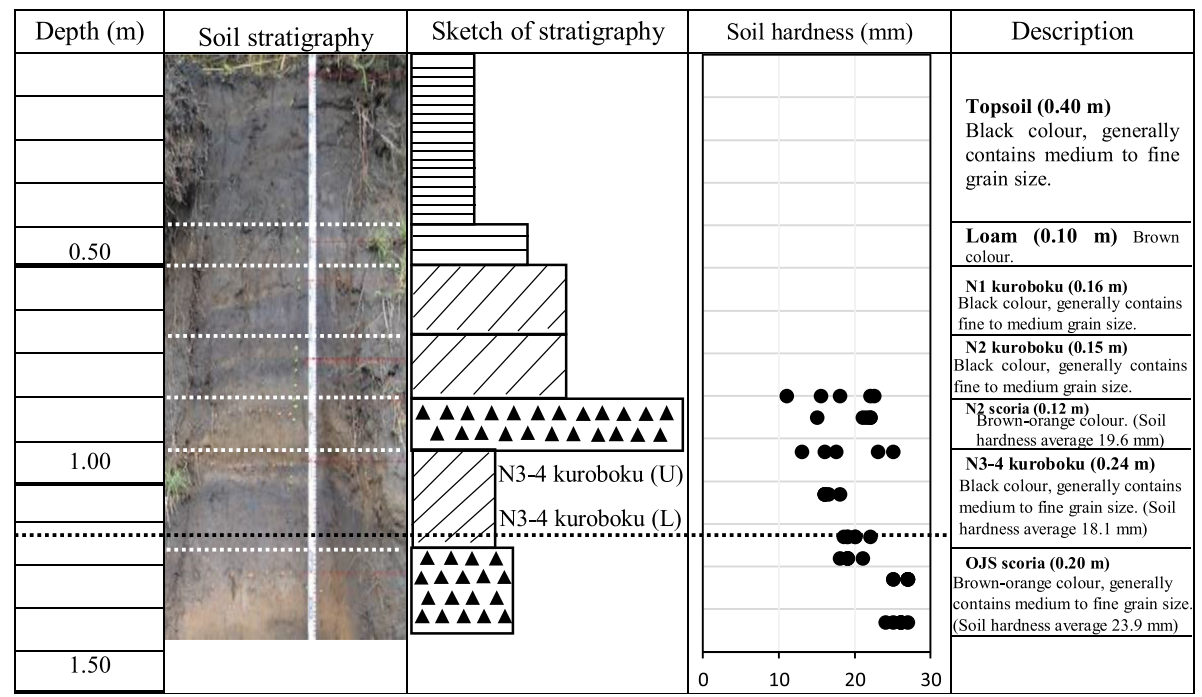

Fig. 2 Soil stratigraphy; dotted lines indicate sliding layer by field observation

two kuroboku layers with two scoria layers, both of which are located on scoria layers (N1 kuroboku is located on the N2 scoria and N3-4 kuroboku is located on OJS scoria). Furthermore, Takadake 2 has three kuroboku layers with two scoria layers: N1 kuroboku and N2 kuroboku are located on the N2 scoria layer and N3-4 kuroboku is located on the OJS scoria layer. N3-4 kuroboku layer is divided into 2 sub-layers in each area, N34 kuroboku (U) and N3-4 kuroboku (L), which aimed at simplifying on the sliding layer estimation in this study.

Dissimilarity in soil hardness is observed between the kuroboku and scoria layers. The soil hardness in Takadake 1 shows N2 scoria has the highest soil hardness value (average $=18.5 \mathrm{~mm}$ ) and topsoil has the lowest soil hardness value (average $=12.6 \mathrm{~mm}$ ). However, the soil hardness value in Takadake 2 shows OJS scoria has the highest value (average $=23.9 \mathrm{~mm}$ ) and N3-4 kuroboku has the lowest value (average $=18.1 \mathrm{~mm}$ ). The low average soil hardness indicates the location of the sliding layer.

Miyabuchi and Daimaru (2004) reported that the sliding layers were formed near the boundary between the kuroboku and scoria layers. In this study, the low average soil hardness value in each area is located at the N3-4 kuroboku layer; therefore, according to the stratigraphic analysis results of the field observations, the N3-4 kuroboku layer is a sliding layer in the studied area.

\section{Physical properties of tephra layers}

The particle size distribution curve (Fig. 3) shows no dissimilarities in the tephra layers in the research area 


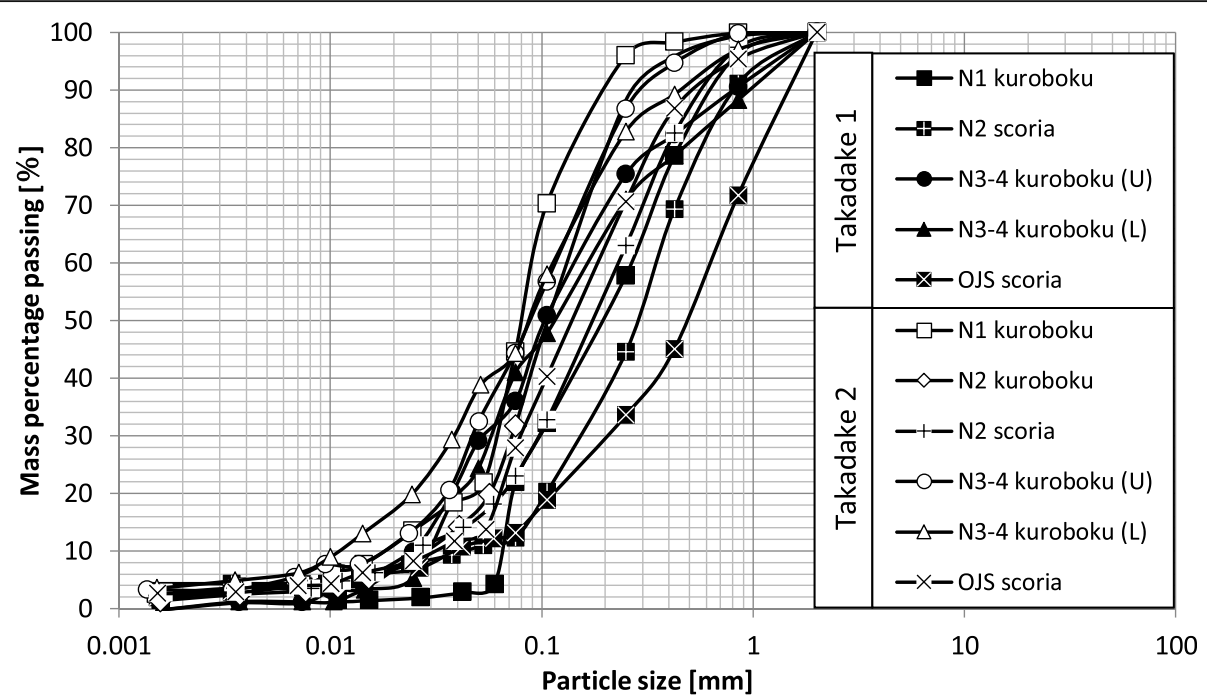

Fig. 3 Particle size distribution curve show that all tephra layers indicate poorly-graded soil material

and all the tephra layers indicate poorly-graded soil material. However, the fine fraction content (less than $0.075 \mathrm{~mm}$ ) on tephra layer (Fig. 4) show the difference between kuroboku and scoria layers, where the kuroboku layers have a higher fine fraction content than the scoria layers in each area. Moreover, in Takadake 1 and Takadake 2 the N3-4 kuroboku (L) layers have the highest fine fraction content (Fig. 4).

Based on the results, the particle size distribution curve does not show any dissimilarity between the kuroboku and scoria layers; however, the fine fraction content shows the dissimilarity between them. For this reason, in this study the particle size distribution curve is difficult to use for estimating the sliding layer, but the fine fraction content can be used as a factor for estimating the sliding layer.
Figure 5 shows the physical properties of the tephra layer, which generally shows that the scoria and kuroboku layers are different. Scoria layers have a low fine fraction content, plasticity index, ignition loss, and organic matter content and a high density of soil particles. Meanwhile, kuroboku layers have high fine fraction content, plasticity index, and ignition loss and low density of soil particles and organic matter content.

Ignition loss and organic matter content were performed to observe the tephra layer carbon content. Previous research performed by Kato (1964) described kuroboku as having humic acids, black in colour, and high carbon content. Unfortunately, the density of soil particles, ignition loss, and organic matter content values present in Fig. 5 are not differentiated between the kuroboku and scoria layers in this study; therefore, these

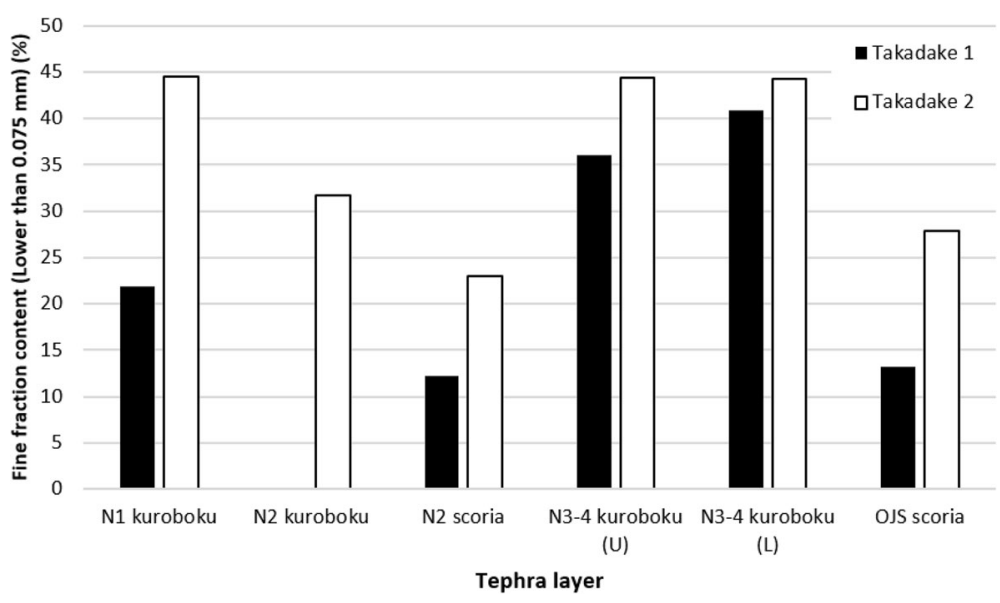

Fig. 4 Fine fraction content on research area shows the dissimilarity between kuroboku and scoria layers 
(a) Takadake 1

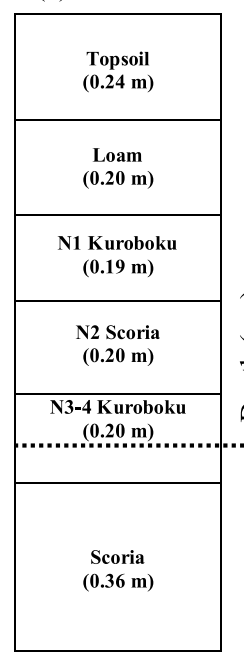
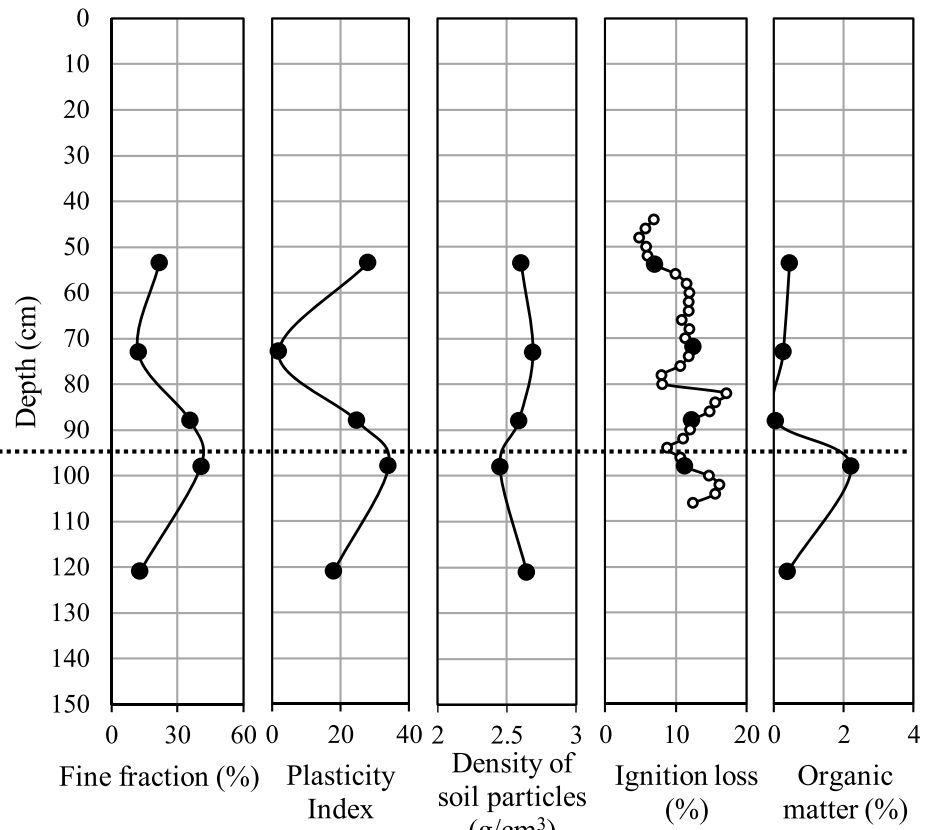

(b) Takadake 2

Fine fraction (\%) Plasticity $\left(\mathrm{g} / \mathrm{cm}^{3}\right)$

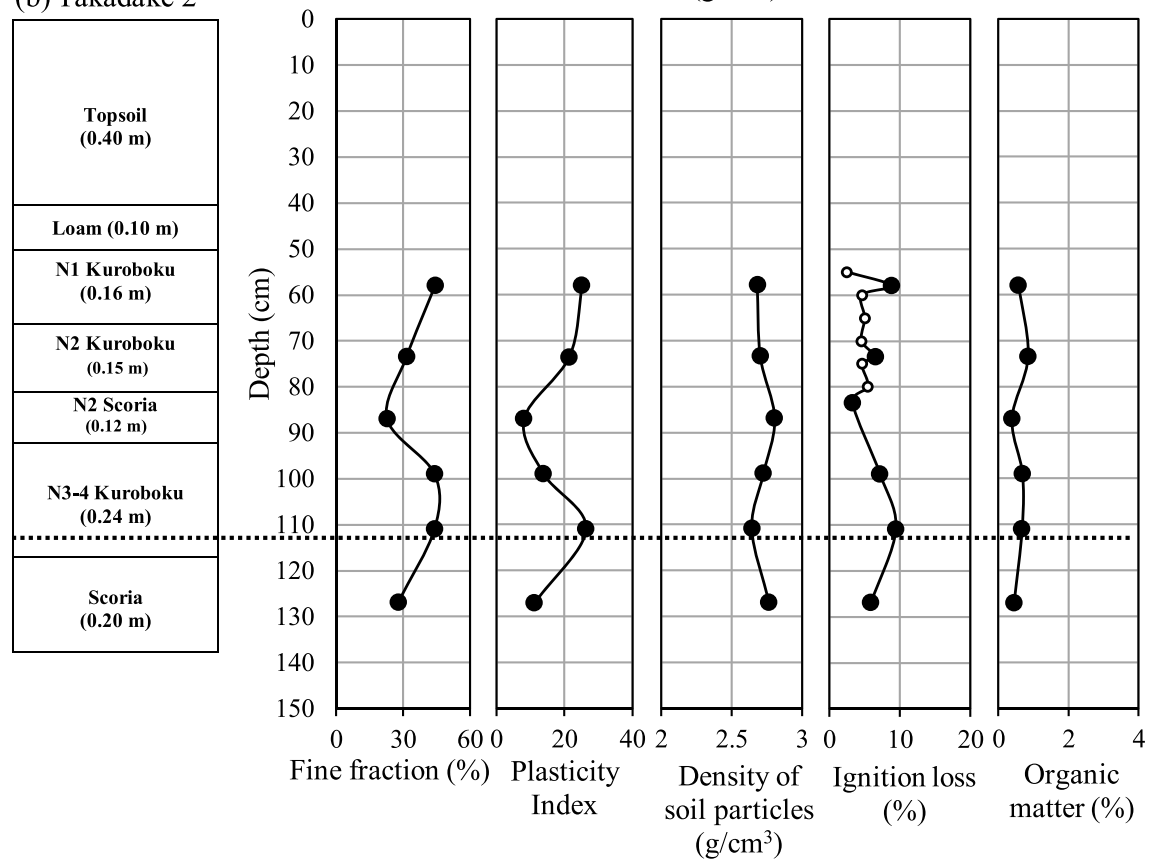

Fig. 5 Physical properties of soil and sliding layer; dotted lines indicated location of sliding layer by field observation

values could not be used as sliding layer indication factors.

Figure 5 shows that the plasticity index is different between the kuroboku and scoria layers. The liquid limit and plastic limit test results are plotted on a plasticity chart (Fig. 6) to classify the tephra layers, which are separated between the sampling location (Takadake 1 and Takadake 2) and the tephra layer type (kuroboku and scoria). The Takadake 1 and Takadake 2 tephra layer data are denoted by filled and un-filled symbols, respectively. Furthermore, the kuroboku and scoria groups are denoted by the line and dotted of ellipse symbols, respectively.

The plotted data in Fig. 6 show a similar classification of the tephra layer for Takadake 1 and Takadake 2. That shows all of the plotted data on kuroboku layers are inorganic silts of high compressibility and organic clays and the OJS scoria layers plotted at the same location as 


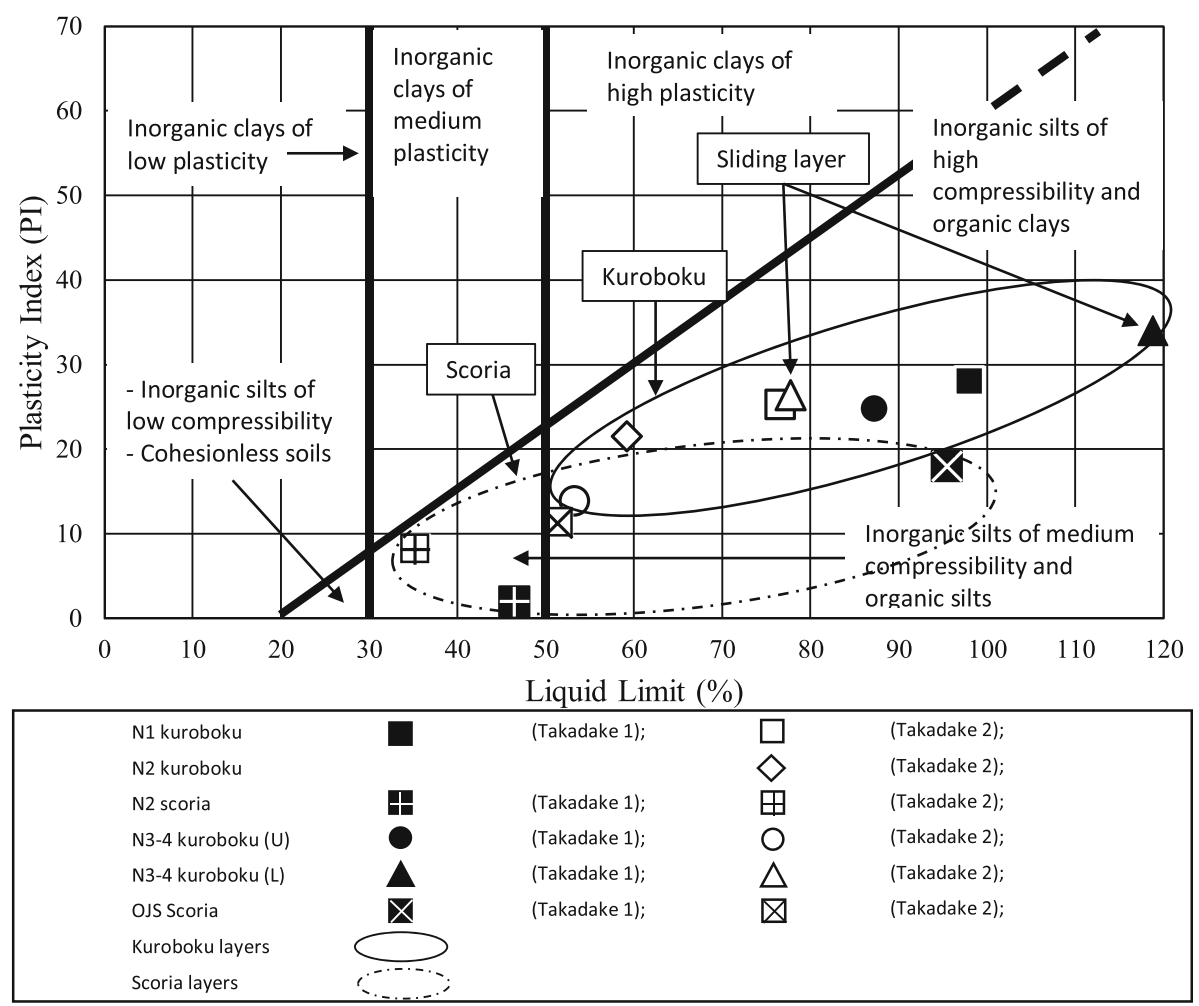

Fig. 6 Plasticity chart shows the dissimilarity between kuroboku and scoria layers

the kuroboku layers. The N2 scoria layers, however, are inorganic silts of medium compressibility and organic silts. The plasticity index and liquid limit values of the kuroboku layers are different, but higher than the scoria layers. The plotted data from Takadake 1 and Takadake 2 both show that the N3-4 kuroboku (L) layer has the highest plasticity index and liquid limit values, while the N2 scoria layer has the lowest plasticity index and liquid limit values. Therefore, the N3-4 kuroboku (L) layers (sliding layers) have the highest values and are plotted in the kuroboku group on the plasticity chart. The plasticity index and liquid limit can be used as factors for estimating the sliding layer.

According to the factors for estimating the sliding layer, a correlation between the plasticity index and fine fraction content is observed in Fig. 7, showing nearly the same result as the plasticity chart. The correlation shows the plotted data are separated between the sampling location (Takadake 1 and Takadake 2) and the tephra layer type (kuroboku and scoria). The Takadake 1 and Takadake 2 tephra layer data are denoted by filled and un-filled symbols, respectively. The data from Takadake 1 fitted to the Takadake 1 trend line, and the data from Takadake 2 also fitted to the Takadake 2 trend line. The trend lines show that the plasticity index is directly proportional to the fine fraction content. Furthermore, the kuroboku and scoria layers are denoted using the line and dotted of ellipse symbols, respectively.

The correlation shows dissimilarity between the kuroboku and the scoria layers. Scoria layers show low fine fraction content and plasticity index values and kuroboku layers show high fine fraction content and plasticity index values. The data from Takadake 1 and Takadake 2 both show that the N3-4 kuroboku (L) layer has the highest plasticity index and fine fraction content values, while the N2 scoria layer has the lowest plasticity index and fine fraction content values. Therefore, the sliding layers (N3-4 kuroboku (L)) are plotted in the kuroboku group on the correlation and has the highest values of plasticity index and fine fraction content. However, the plots of this correlation have a wide scattering, which could be caused by the difference in soil materials in the different volcanic activity periods and the historical landslides in the Aso volcanic mountains.

\section{Conclusion}

The soil materials in the shallow landslides on the Aso volcanic mountains were divided by volcanic activity period and laboratory tests were performed to observe the physical properties of each layer. Characteristics of tephra 


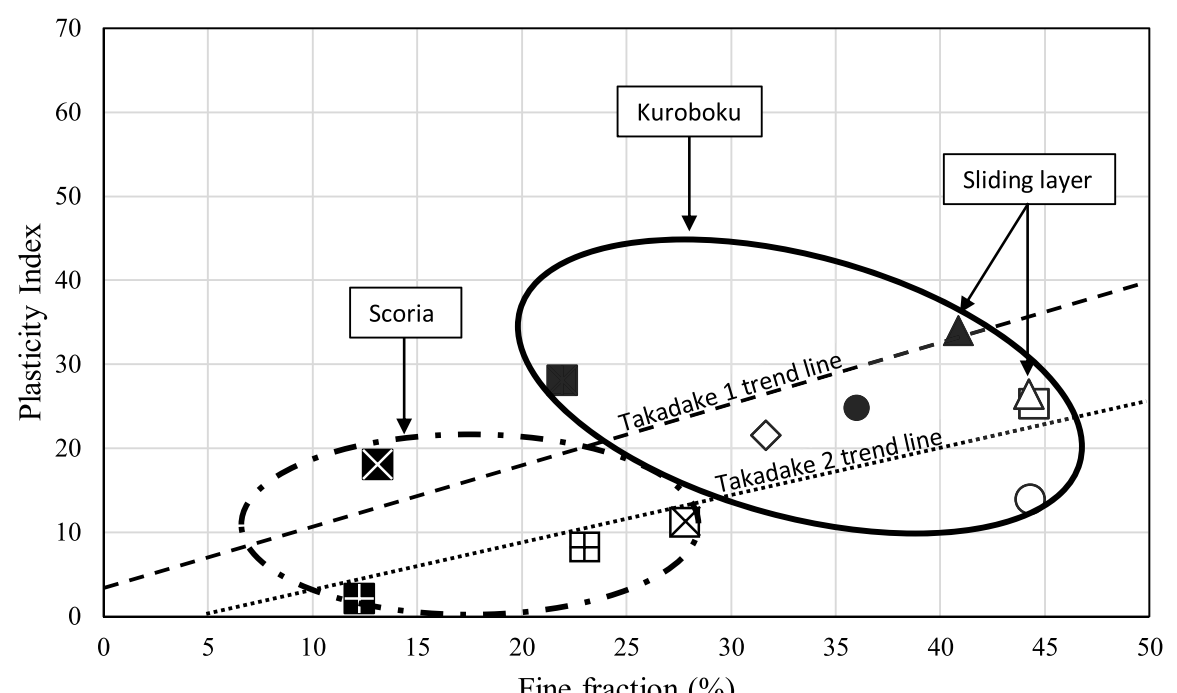

Fine fraction $(\%)$

\begin{tabular}{|c|c|c|c|c|}
\hline N1 kuroboku & & (Takadake 1); & $\square$ & (Takadake 2); \\
\hline N2 kuroboku & & & $\diamond$ & (Takadake 2); \\
\hline N2 scoria & 甲 & (Takadake 1); & 由 & (Takadake 2); \\
\hline N3-4 kuroboku (U) & & (Takadake 1); & 0 & (Takadake 2); \\
\hline N3-4 kuroboku (L) & & (Takadake 1); & $\triangle$ & (Takadake 2); \\
\hline OJS Scoria & $X$ & (Takadake 1); & $\bigotimes$ & (Takadake 2); \\
\hline Trend lines & $----\cdot$ & (Takadake 1); & ...................... & (Takadake 2); \\
\hline Kuroboku layers & & & & \\
\hline Scoria layers & & & & \\
\hline
\end{tabular}

Fig. 7 Correlation between fine fraction content (\%)-plasticity index shows dissimilarity between kuroboku and scoria

layers have been observed from the physical properties of soil by considering the stratigraphic analysis of field observations. The kuroboku layers were located on the scoria layers. Moreover, the average soil hardness value of the kuroboku layers is lower than the scoria layers and the low average soil hardness value indicates the location of sliding layer. The stratigraphic analysis results of the field observations show that the N3-4 kuroboku layer is the sliding layer in the studied area.

The laboratory test results show that the kuroboku and scoria layers have different physical properties of soil. The kuroboku layers have higher fine fraction content and plasticity index values than the scoria layers. In the studied areas, the correlation between the plasticity index and fine fraction content clearly shows the N3-4 kuroboku (L) layers (sliding layers) have the highest plasticity index and fine fraction content values and that are plotted in the kuroboku group. According to these results, the fine fraction content and plasticity index can be used as factors for estimating the sliding layer in the studied area. Additionally, the sliding layer in the volcanic area may have high fraction content and plasticity index values.

\section{Acknowledgments}

The completion of field observation on this paper could not have been possible without the participation and assistance of other members of this project. Thank you so much for reviewers from Geoenvironmental Disasters Journal, with your comments this journal has improved on this state.

\section{Authors' contributions}

All authors went to the landslide sites and choose a location to expose the tephra layer, took a samples and did the field investigation (identify the tephra layer, measures soil hardness). MLI and SG analysed and interpreted the physical property tests regarding the soil layers at the landslide sites. All authors read and approved the final manuscript.

\section{Funding}

Part of this study was carried out by Japan Society for the Promotion of Science Grants-in-Aid for Scientific Research Grant-in-Aid for Scientific Research (B) $17 \mathrm{H} 03303$.

\section{Availability of data and materials}

The datasets used and/or analysed during the current study are available from the corresponding author on reasonable request.

\section{Competing interests}

Authors have no competing interests on this study.

\section{Author details}

${ }^{1}$ Civil Management and Engineering Major, Environmental and Social System Science Course, Integrated Graduate School of Medicine, Engineering, and Agricultural Sciences, University of Yamanashi, Kofu, Japan. ${ }^{2}$ Faculty of Engineering, Graduate Faculty of Interdisciplinary Research, University of Yamanashi, Kofu, Japan. ${ }^{3}$ Graduate School of Agriculture, Ehime University, Matsuyama, Japan. ${ }^{4}$ Graduate School of Environmental Informations, Teikyo Heisei University, Tokyo, Japan. ${ }^{5}$ Graduate School of Education, Akita University, Akita, Japan. ${ }^{6}$ Graduate School of Science and Technology, Gunma University, Kiryu, Japan. ${ }^{7}$ Domestic Consulting Operations,

Nippon-Koei Co. Ltd., Hirosaki, Japan. 
Received: 27 February 2020 Accepted: 21 August 2020

Published online: 02 October 2020

\section{References}

Condie KC (1993) Chemical composition and evolution of the upper continental crust: contrasting results from surface samples and shales. Chem Geol 104(14):1-37 https://doi.org/10.1016/0009-2541(93)90140-E

Goto S, Kimura T (2019) Introduction of the special issue on "Toward the prediction of shallow landslides induced by heavy rainfalls on tephracovered slopes". Journal of the Japan Landslide Society 56:211-217 https:// doi.org/10.3313/jls.56.211 (in Japanese)

Higaki D, Li X, Hayashi I, Tsou C, Kimura T, Hayashi S, Sato G, Goto S (2019) Geomorphological setting of shallow landslides by heavy rainfall on tephracovered slopes of Aso volcano, southwest Japan. Journal of the Japan Landslide Society 56:218-226 https://doi.org/10.3313/jls.56.218 (in Japanese with English abstract)

Kato Y (1964) Some problems on the genesis of "Kurboku" soils. Quaternary Res 3(4):212-222 (in Japanese with English abstract)

Kimura T, Goto S, Sato G, Wakai A, Hayashi S, Higaki D (2019) Evaluation of landslide susceptibility by slope stability analysis using an estimated distribution of tephra deposits-a case study in the northeastern part of Aso caldera-. Journal of the Japan Landslide Society 56:240-249 https://doi.org/ 10.3313/jls.56.240 (in Japanese with English abstract)

Miyabuchi Y, Daimaru H (2004) The June 2001 rainfall-induced landslides and associated lahars at Aso volcano, southwestern Japan: implication for hazard assessment. Acta Vulcanol 16(1-2):21-36

Miyabuchi Y, Daimaru H, Komatsu Y (2004) Landslides and lahars triggered by the rainstorm of June 29, 2001, at Aso volcano, Southwestern Japan. Tran Jpn Geomorphological Union 25-1:23-43 (in Japanese with English abstract)

Ono K, Watanabe K (1985) Geological map of Aso volcano (1:50,000), Geological map of volcanoes 4. In: Geological survey of Japan (in Japanese with English abstract)

Sato G, Goto S, Kimura T, Hayashi S, Istiyanti ML, Komori J (2017) Gravitational deformation as a precursor of shallow landslide within tephra-covered slope deposits in the Aso caldera, Japan. Journal of the Japan Landslide Society 54(5):199-204 https://doi.org/10.3313/jls.54.199 (in Japanese with English abstract)

Sato G, Wakai A, Goto S, Kimura T (2019) Strength characteristics of gravitationally deformed slope deposits of tephra and kuroboku soils in the Aso caldera, Japan -Application of revised vane-shear-cone test for estimating shear strength-. Journal of the Japan Landslide Society 56:250-253 https://doi.org/ 10.3313/jls.56.250 (in Japanese with English abstract)

Shimizu O, Ono M (2016) Relationship of tephra stratigraphy and hydraulic conductivity with slide depth in rainfall-induced shallow landslides in Aso Volcano, Japan. Landslides 13(3):577-582 https://doi.org/10.1007/s10346-0150666-2

The Japanese Geotechnical Society (2015) Japanese geotechnical society standards laboratory testing standards of geomaterials, vol 1

\section{Publisher's Note}

Springer Nature remains neutral with regard to jurisdictional claims in published maps and institutional affiliations.

\section{Submit your manuscript to a SpringerOpen ${ }^{\circ}$ journal and benefit from:}

- Convenient online submission

- Rigorous peer review

- Open access: articles freely available online

- High visibility within the field

- Retaining the copyright to your article

Submit your next manuscript at $\boldsymbol{\nabla}$ springeropen.com 